\title{
Allelopathic effects and mechanisms of Cochlodinium geminatum isolated from the Pearl River Estuary
}

\author{
Jiaying Yan ${ }^{1} \cdot$ Jingya Liu ${ }^{1} \cdot$ Yu Cai $^{1} \cdot$ Shunshan Duan ${ }^{1} \cdot$ Yingzhong Tang ${ }^{2} \cdot$ Ning Xu $^{1}$
}

Received: 10 October 2018 / Revised and accepted: 6 March 2019/Published online: 27 March 2019

(C) The Author(s) 2019

\begin{abstract}
The dinoflagellate Cochlodinium geminatum can form near-monospecific blooms which have occurred at the same location in the South China Sea repeatedly in the last decade. Here, we demonstrate the allelopathic effects of C. geminatum isolated from the bloom waters of the Pearl River Estuary, South China Sea, in August 2011, which inhibited four of six co-occurring phytoplankton species tested. Inhibition increased with rising cell density and reached a maximum in the declining growth stage. Four different $C$. geminatum culture components negatively affected growth of Akashiwo sanguinea in order of decreasing percent inhibition: sonicated culture, filtrate of sonicated culture, whole-cell culture and filtrate of whole-cell culture. The highest inhibition was at $25^{\circ} \mathrm{C}$ and salinities of $30 \mathrm{PSU}$ and light intensities of $100 \mu \mathrm{mol}$ photons $\mathrm{m}^{-2} \mathrm{~s}^{-1}$. Overall, our study showed that C. geminatum could inhibit growth of phytoplankton competitors during succession of phytoplankton community, achieving nearly monospecific blooms, and the allelopathic effects were regulated by environmental factors.
\end{abstract}

Keywords Algal blooms $\cdot$ Cochlodinium geminatum $\cdot$ Dinoflagellate $\cdot$ Phytoplankton $\cdot$ Allelopathy $\cdot$ Competitions $\cdot$ Stress $\cdot$ Marine ecology

\section{Introduction}

Many species in the unarmored dinoflagellate genus Cochlodinium (Gymnodiniales, Dinophyceae), especially Cochlodinium polykrikoides and Cochlodinium fulvescens, can cause harmful algal blooms (HABs) commonly and globally (Lee 2008; Tang and Gobler 2009; Kudela and Gobler 2012; Iwataki et al. 2015). In recent decades, the HABs caused by Cochlodinium have been frequently reported in some Asian countries, particularly Korea and Japan (Yamatogi et al. 2006; Matsuoka and Iwataki 2009; Matsuoka et al. 2010; An et al. 2015; Lim et al. 2017). In China, however, emerging blooms of Cochlodinium geminatum occurred twice in the coastal waters of the Pearl River Estuary, in April and October-November

Jiaying Yan and Jingya Liu contributed equally to this work.

Ning Xu

txuning@jnu.edu.cn; txuning@163.com

1 Institute of Hydrobiology, Jinan University, 510632 Guangzhou, People's Republic of China

2 Key Laboratory of Marine Ecology and Environmental Sciences, Institute of Oceanology, Chinese Academy of Science, 266071 Qingdao, People's Republic of China
2006. Cochlodinium geminatum was regarded as a newly recorded HAB-causing dinoflagellate in the South China Sea (Ou et al. 2010; Shen et al. 2012). Moreover, C. geminatum blooms recurred in October 2009 and August 2011 in the same area of the Pearl River Estuary (Wang et al. 2011; Pang et al. 2015; Zhang et al. 2017), causing massive fish mortalities and economic losses (Guo et al. 2014). It seems that $C$. geminatum is now a common bloom species in the Pearl River Estuary. So far, little is known on the provenance of $C$. geminatum. However, recent study showed that $C$. geminatum can produce resting cyst via germinating cysts in sediment samples from the South China Sea and Bohai Sea, China (Lan and Gu 2014), which suggested that this species may be distributed worldwide through ballast water.

Many studies have shown that dinoflagellate species often have low growth rates compared with other phytoplankton (Steidinger and Haddad 1981; Smayda 1997). This means that it should be difficult for $C$. geminatum to overcome other phytoplankton species and form blooms. Nonetheless, according to field investigations, $C$. geminatum can form nearmonospecific and persistent blooms (Ou et al. 2010; Wang et al. 2011). For example, the highest cell density of C. geminatum was $\sim 3 \times 10^{7}$ cells $\mathrm{L}^{-1}$ during the bloom in 2009 , accounting for more than $99 \%$ of phytoplankton density (Shen et al. 2012; Pang et al. 2015). Additionally, water 
samples of the $C$. geminatum bloom in 2009 inhibited growth of Prorocentrum micans and Heterosigma akashiwo (Wang et al. 2011). A possible explanation for its unusual dominance is that $C$. geminatum may possess other ecological strategies, such as producing allelochemicals to outcompete cooccurring phytoplankton species.

The effects of allelopathy during HABs remain unclear, although it has been hypothesized to play an important role in species succession (Keating 1977) and the formation or maintenance of harmful algal blooms (Smayda 1997). Cleberc et al. (2007) found that filtrate from cultures of Cylindrospermopsis raciborskii (Cyanobacteria) and the lake water sampled during a bloom of $C$. raciborskii had an allelopathic effect on most target species. Furthermore, the allelopathic effect can be influenced by abiotic factors, such as irradiation, temperature, and salinity. Uronema confervicolum (Chlorophyta) had a higher production of allelopathic compounds under higher light intensity (Allen et al. 2017). The allelopathic effect is also temperature-dependent, as toxic Microcystis aeruginosa (Cyanobacteria) strains inhibited the growth of Chlorella vulgaris (Chlorophyta) more at high temperatures $\left(\geq 25^{\circ} \mathrm{C}\right.$ ) (Ma et al. 2015). Furthermore, the allelochemical production of the picocyanobacterium Synechococcus sp. was regulated by light, temperature, and salinity (Śliwińska-Wilczewska et al. 2016). Moreover, since C. geminatum is difficult to isolate and culture under artificial conditions, relationships between its growth and basic environmental factors remain unknown. However, it is conceivable that these environmental factors may regulate adaptive strategies of $C$. geminatum, such as allelopathic effects, and result in blooms under suitable conditions (Shen et al. 2012). Thus, whether C. geminatum is allelopathic to co-occurring phytoplankton, what exactly the function of any allelopathy is within its blooms, and how environmental factors regulate its growth and allelopathic effects are unanswered.

This study explores potential allelopathic effects of C. geminatum on six co-occurring phytoplankton species. We investigated how cell density, growth stage, and different extracts of $C$. geminatum cultures influenced allelopathic performance. Furthermore, we explored how environmental factors such as irradiation, temperature, and salinity regulated its allelopathic activity.

\section{Materials and methods}

\section{Strains and culture conditions}

Two clonal strains of Cochlodinium geminatum (JX25 and JX26) were established by micropipetting single cells from bloom samples collected using a $20-\mu \mathrm{m}$ phytoplankton net from the coastal water of Zhuhai, Guangdong, China, in August 2011. The species was identified and classified using light and scanning electron microscopy as well as LSU and SSU rDNA sequences. Total DNA of $C$. geminatum was extracted from $10 \mathrm{~mL}$ of exponentially growing culture using a plant DNA extraction kit (Tiangen, China) according to the manufacturer's protocol. Approximately 1400 bp of the LSU rDNA was amplified using primers of GmLsF (forward, 5' aggattccethagtaatggcgaatg-3') and GmLsR (reverse, 5'ggtcgaatagaaccatttcgtcacc-3'), and an approximately $1661 \mathrm{bp}$ of the SSU rDNA was amplified using primers PsF (forward, 5'-tgccagtagtcatatgcttgtctc-3') and PsR (forward, 5'tccttcygcaggttcacctacgga- $\left.3^{\prime}\right)$. The PCR reactions were performed with a final volume of $25 \mu \mathrm{L}$, containing $9.5 \mu \mathrm{L}$ $\mathrm{ddH}_{2} \mathrm{O}, 12.5 \mu \mathrm{L} 2 \times$ Taq PCR MasterMix, $1 \mu \mathrm{L}$ of each PCR primer $(10 \mathrm{mmol})$, and $1 \mu \mathrm{L}$ of the DNA template. The amplification was performed with an initial denaturation at $94{ }^{\circ} \mathrm{C}$ for 5 min, 35 cycles at $94^{\circ} \mathrm{C}$ for $20 \mathrm{~s}, 55^{\circ} \mathrm{C}$ for $30 \mathrm{~s}$, and $72^{\circ} \mathrm{C}$ for $2 \mathrm{~min}$, and a final elongation step of $10 \mathrm{~min}$ at $72^{\circ} \mathrm{C}$. The PCR products were checked in a $1 \%$ agarose gel containing ethidium bromide and visualized with ultraviolet light. The targeted bands were purified by an agarose gel DNA fragment recovery kit (GENEray Biotechnology, China), ligated with pMD-18T cloning vector (TaKaRa, Japan), and then sequenced (Sangon, Shanghai, China). The sequences were deposited in GenBank with accession numbers MF445291 (LSU) and MF445297 (SSU). The detailed method and identification results are included in another study (Hu et al. unpublished).

The target algal strains used in the co-culturing experiments included three species of dinoflagellates (Akashiwo sanguinea AS2, Karlodinum veneficum JX24 and Prorocentrum micans JX8), a diatom (Skeletonema costatum JX6), a haptophyte (Prymnesium parvum JX12), and a cryptophyte (Rhodomonas salina CCMP1319). All JX strains were collected from the Pearl River Estuary, established and maintained in our laboratory. Strain CCMP1319 was donated by Christopher J. Gobler from Stony Brook University. Culture AS2 was provided by Y. Z. Tang and isolated from Chesapeake Bay.

Cultures were grown in natural seawater with a salinity of 18 PSU with the $\mathrm{f} / 2$ medium (Guillard 1975) under conditions of $20 \pm 1{ }^{\circ} \mathrm{C}, \sim 100 \mu \mathrm{mol}$ photons $\mathrm{m}^{-2} \mathrm{~s}^{-1}$ and a photoperiod of 12:12 h (light/dark).

\section{Experiments}

\section{Experiment 1: C. geminatum allelopathy to co-occurring phytoplankton}

Cochlodinium geminatum in the exponential growth phase (4 days after inoculation) was respectively co-cultured with the six species of microalgae described above in $10-\mathrm{mL}$ culture tubes for $72 \mathrm{~h}$ under the same conditions used for maintaining cultures. The $\mathrm{f} / 2$-Si medium was added at the beginning of the experiment to ensure sufficient nutrition in the experiment. Initial concentrations of $C$. geminatum and the target algae were 
500 cells $\mathrm{mL}^{-1}$. Monocultures of $C$. geminatum and target species under the same conditions were used as controls. All treatments and controls were in triplicate. During the incubation, the morphological changes and behaviors of cells were observed and photographed every $24 \mathrm{~h}$ under a light microscope (Nikon Eclipse E200, Japan). At the end of incubation, some cultures were fixed with Lugol's solution (final concentration of $2 \%$ ) for counting under the microscope.

\section{Experiment 2: variations in C. geminatum allelopathy among strains, growth phases, and density}

Effects of different strains, growth stage, and cell density of C. geminatum were investigated for inhibition of A. sanguinea. Because A. sanguinea was sensitive to C. geminatum in the prior algal bioassay and was large enough to count, it was chosen as a model target alga in the following experiments.

Two C. geminatum strains, JX25 and JX-26, were chosen to compare their responses to allelopathy. After growing for 4 days, JX25 or JX-26 (final cell density 500 cells mL ${ }^{-1}$ ) were added into a $10-\mathrm{mL}$ culture tube for co-culture with A. sanguinea AS2 for $72 \mathrm{~h}$ under the same conditions used for maintaining cultures. The $\mathrm{f} / 2$-Si medium was added at the beginning of the experiment to ensure sufficient nutrition in the experiment. Monoculture of A. sanguinea AS2 in $\mathrm{f} / 2-\mathrm{Si}$ medium was taken as a control. All treatments and controls were in triplicate. The initial cell density of AS2 in the experiment was also 500 cells $\mathrm{mL}^{-1}$. After $72 \mathrm{~h}$ of culturing, samples were fixed with Lugol's solution (final concentration 2\%) for counting under the microscope.

For growth stage and cell density assays, we conducted experiments with $C$. geminatum JX25 cultures at different growth stages: middle exponential, stationary, and declining stages. Cultures were filtered with $0.22 \mu \mathrm{m}$ pore size polycarbonate filter and then diluted with the $\mathrm{f} / 2$-Si medium to a series of cell-free culture filtrates with corresponding cell density gradients of 100, 500, 1000, 2000, and 2500 cells $\mathrm{mL}^{-1}$. Akashiwo sanguinea AS2 grew in different-stage and different-cell density culture filtrates of JX25 for $72 \mathrm{~h}$. The f/ 2-Si medium was added at the beginning of the experiment to ensure sufficient nutrition in the experiment. All treatments and controls were in triplicate. Sampling and counting methods were as described above.

\section{Experiment 3: allelopathy of different fractions of $C$. geminatum cultures}

The different components of $C$. geminatum cultures were tested for inhibition of $A$. sanguinea growth. We prepared four different components of $C$. geminatum culture: whole-cell culture, culture filtrate, sonicated culture, and sonicated and filtered culture. After incubation for 4 days, we obtained
$250 \mathrm{~mL}$ cultures of $C$. geminatum JX25 for later experiments. First, culture filtrate was obtained by filtration of $50 \mathrm{~mL}$ of the cultures through a $0.22 \mu \mathrm{m}$ polycarbonate filter to remove cells. Then, other $100 \mathrm{~mL}$ cultures were sonicated with a high power sonicator (JYD-900L, China) and we checked under a microscope to ensure acquiring broken cell culture. Last, to obtain the sonicated and filtered culture, we took $50 \mathrm{~mL}$ of the sonicated cultures and used it for a further filtration with a $0.22 \mu \mathrm{m}$ polycarbonate filter.

Akashiwo sanguinea was co-cultured with the four components of $C$. geminatum JX25. The initial cell densities for C. geminatum and A. sanguinea were 500 cells $\mathrm{mL}^{-1}$. All experiments were performed in $10-\mathrm{mL}$ culture tubes for $72 \mathrm{~h}$ under the same conditions used for maintaining cultures. The $\mathrm{f} / 2$-Si medium was added at the beginning of the experiment to ensure sufficient nutrition in the experiment. Monoculture of A. sanguinea at the same cell density in the $\mathrm{f} / 2$-Si medium was used as a control. All treatments and controls were in triplicate. Every $24 \mathrm{~h}, 1 \mathrm{~mL}$ samples were taken out and fixed with Lugol's solution (final concentration 2\%) for counting under the microscope.

\section{Experiment 4: environmental factors affecting allelopathy of $C$. geminatum}

To explore the effects of light, temperature, and salinity on allelopathic activities of $C$. geminatum, strain JX25 was cultured under different conditions: (a) two light intensities of 5 and $100 \mu \mathrm{mol}$ photons $\mathrm{m}^{-2} \mathrm{~s}^{-1}$; (b) three temperatures of 15 , 20 , and $25^{\circ} \mathrm{C}$; and (c) four salinities of $10,18,25$, and 30 PSU. Other conditions were as for the maintaining cultures if not noted. Strain JX25 was grown under the above conditions for at least two transfers, before use in experiments. The exponential cultures were added into $10-\mathrm{mL}$ culture tubes (initial cell density 800 cells $\mathrm{mL}^{-1}$ ) to co-culture with A. sanguinea AS2 for $72 \mathrm{~h}$ under the same conditions used for maintaining cultures. The $\mathrm{f} / 2$-Si medium was added at the beginning of the experiment to ensure sufficient nutrition in the experiment. The AS2 cultured alone in the $\mathrm{f} / 2$-Si medium and the same condition (light intensities, temperatures, and salinities) as experimental group was the control. The initial cell density of AS2 in the experiment was 500 cells $\mathrm{mL}^{-1}$. All treatments and controls were in triplicate. Every $24 \mathrm{~h}, 1 \mathrm{~mL}$ samples were taken and fixed with Lugol's solution (final concentration $2 \%$ ) for counting under the microscope.

\section{Statistical analyses}

Inhibition percentage of $C$. geminatum to target algae was calculated using Eq. 1:

$N_{\text {inhibition }}=\frac{1-N_{\text {treatment }}}{N_{\text {control }}} \times 100$ 
where $N_{\text {inhibition }}$ is the inhibition percentage, $N_{\text {treatment }}$ is the number of live target algae in treatments, and $N_{\text {control }}$ is the number of live target algae in controls.

In experiments $1,2,3$, and 4 , allelopathic significance of $C$. geminatum was tested with $t$ test in Minitab v.17. Twosample $t$ tests were used for comparing the data under different irradiation conditions. Multiple comparisons were conducted in R, using Tukey's HSD in the multiple comparisons package to assess the differences among treatments in experiments 2 , 3 , and 4 . In all cases, significance levels were set at $p<0.05$.

\section{Results}

In this study, the experiments only caused a minor fluctuation of $\mathrm{pH}$. The $\mathrm{pH}$ in these experiments ranged from 7.4 to 8.6, below noxious effects level on marine protists (Pedersen and Hansen 2003; Xu et al. 2015). Moreover, ambient nitrate and phosphate concentrations were above 70 and $2.96 \mu \mathrm{M}$ after $72 \mathrm{~h}$ co-culturing, which means nutrients were above the halfsaturation of these nutrients for most phytoplankton (Smayda 1997). Thus, nutrients unlikely influenced the results.

\section{C. geminatum allelopathy to co-occurring phytoplankton}

Co-culture experiments showed that $C$. geminatum JX25 had different effects on the six kinds of microalgae (Fig. 1). After incubation for $72 \mathrm{~h}$, JX25 strongly inhibited growth of $P$. micans, A. sanguinea, $K$. veneficum, and $R$. salina, especially $P$. micans with an inhibition rate of $40 \%(p<0.01, t$ test). In contrast, growth of $P$. parvum was markedly promoted by JX25 with a promotion percentage of $55 \%$ ( $p<0.01, t$ test). However, JX25 had no significant effect on $S$. costatum growth $(p>0.05, t$ test).

\section{Variations in C. geminatum allelopathy among strains, growth phases, and density}

Strains JX25 and JX-26 both significantly inhibited growth of A. sanguinea after $72 \mathrm{~h}$ of co-culture ( 29.5 and $32.4 \%$, respectively), but with no significant difference in inhibition effect between JX25 and JX26 ( $p>0.05)$.

Filtrates of $C$. geminatum JX25 in different stages showed allelopathic activity on $A$. sanguinea, and this was enhanced with increasing cell density of JX25 (Fig. 3). All treatments in this experiment displayed significant inhibition effects on A. sanguinea except the 100 cells $\mathrm{mL}^{-1}$ of mid-exponential growth stage (Fig. 2) $(p<0.05, t$ test). When initial cell density was 2500 cells $\mathrm{mL}^{-1}$, A. sanguinea showed the highest inhibition in declining growth stage of $C$. geminatum $(44.3 \%)$, followed by stationary growth stage $(41.1 \%)$ and midexponential growth stage (36.8\%) (Fig. 2a) ( $p>0.05$, multiple comparisons). When initial cell density was 2000 cells $\mathrm{mL}^{-1}$, A. sanguinea showed the highest inhibition in declining growth stage of $C$. geminatum ( $41.1 \%$ ), followed by stationary growth stage $(41.0 \%)$ and mid-exponential growth stage (36.2\%) (Fig. 2a) ( $p>0.05$, multiple comparisons). Moreover, the inhibition effect on $A$. sanguinea was significantly enhanced with increasing cell density in every growth stage of C. geminatum (Fig. 2b) ( $p<0.05$, multiple comparisons).

\section{Allelopathic activity of different fractions of $C$. geminatum cultures}

Four $C$. geminatum culture fractions including whole-cell culture, culture filtrate, sonicated culture, and sonicated culture filtrate all displayed significant inhibition effects on $A$. sanguinea (Fig. 3) ( $p<0.05, t$ test). After incubation for $72 \mathrm{~h}, A$. sanguinea showed the highest inhibition in sonicated culture $(66.7 \%)$, followed by sonicated and filtered culture (47.5\%) and wholecell culture $(35 \%)$, with the lowest inhibition rate for culture filtrate (17.5\%). Sonicated culture clearly had the strongest inhibition of A. sanguinea with the highest inhibition of about $80 \%$ at $48 \mathrm{~h}$. Compared to sonicated culture, sonicated culture filtrate had lower inhibition of about $50 \%$ at the end of the experiment. Whole-cell culture exhibited stronger inhibition of A. sanguinea with prolonged incubation time. However, the inhibition of culture filtrate to A. sanguinea was the lowest and nearly the same at 24,48 , and $72 \mathrm{~h}$. The order about inhibition effect of four different $C$. geminatum culture components to $A$. sanguinea is as follows: sonicated culture, filtrate of sonicated culture, wholecell culture, and filtrate of whole-cell culture (strong to weak, $p<0.05$, multiple comparisons).

\section{Environmental factors affecting allelopathy of C. geminatum cultures}

Cochlodinium geminatum JX25 grew well in both high $\left(100 \mu \mathrm{mol}\right.$ photons $\left.\mathrm{m}^{-2} \mathrm{~s}^{-1}\right)$ and low $\left(5 \mu \mathrm{mol}\right.$ photons $\left.\mathrm{m}^{-2} \mathrm{~s}^{-1}\right)$ light intensity for $72 \mathrm{~h}$ (Fig. 4a). The growth of JX25 under the two light conditions showed no significant difference $(p>0.05$, two-sample $t$ tests). However, JX25 grown at high light intensity had a stronger inhibition effect than at low light intensity ( $p<0.05$, two-sample $t$ tests) (Fig. 4b). Inhibition percentages toward A. sanguinea with high light condition were 13, 16.8, and $21.8 \%$ at 24,48 , and $72 \mathrm{~h}$, respectively, but the average inhibition under low light was only $1.2 \%$ at $72 \mathrm{~h}$.

Cochlodinium geminatum JX25 also grew well across the wide temperature range of $15-25^{\circ} \mathrm{C}$ (Fig. 4c). There were no significant differences in growth rate between different temperature treatments ( $p>0.05$, multiple comparisons) within $72 \mathrm{~h}$. However, JX25 grown at different temperatures exhibited varying inhibition abilities (Fig. 4d). Inhibition percentages toward A. sanguinea at $20^{\circ} \mathrm{C}$ were $12.6,18.9$, and $20.9 \%$ at 24,48 , and $72 \mathrm{~h}$, respectively, showing a time effect. 
Fig. 1 Allelopathic effects of C. geminatum on growth of six co-occurring phytoplankton species at $72 \mathrm{~h}$. Initial cell densities of C. geminatum and six competing phytoplankton species were each 500 cells $\mathrm{mL}^{-1}$. Each data point represents the mean of triplicates $(n=3)$. Error bars stand for +1 standard deviation of $n=3$. Significance is marked as $* p<0.05$ and $* * p<0.01$, respectively $(t$ test)

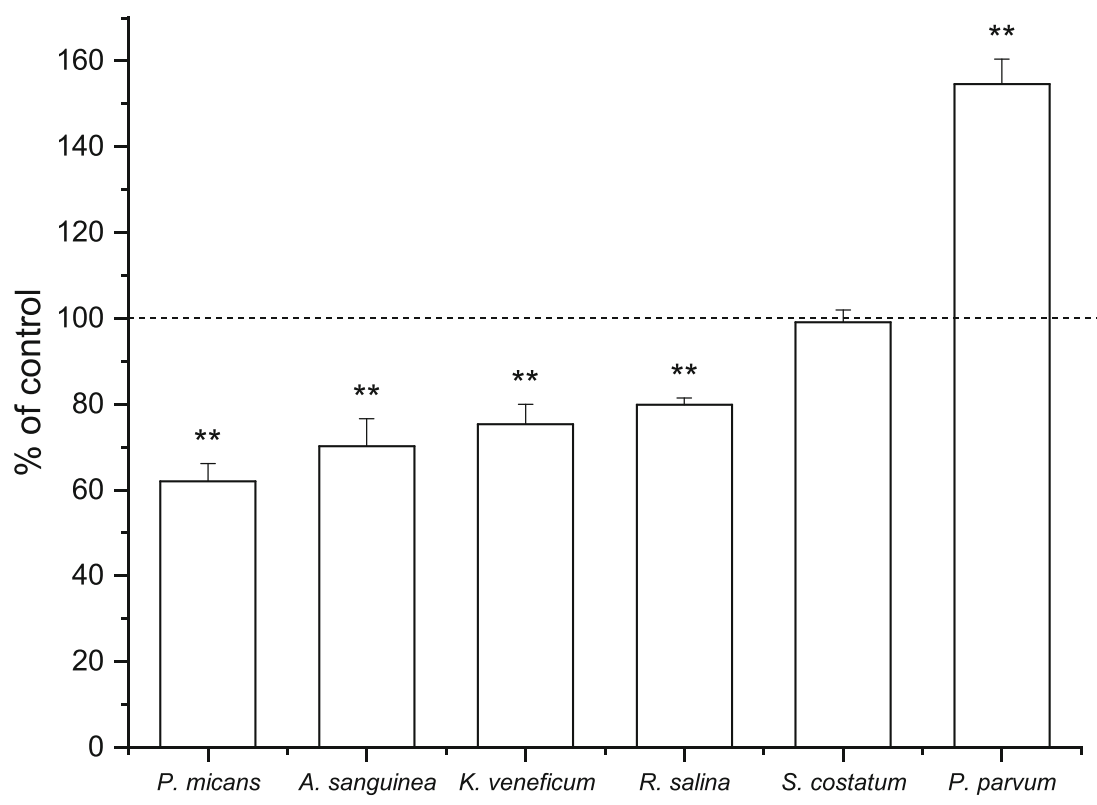

Treatments of 20 and $25{ }^{\circ} \mathrm{C}$ had nearly the same inhibition for A. sanguinea; however, there was no significant inhibition at $15^{\circ} \mathrm{C}(p>0.05, t$ test $)$ in 48 and $72 \mathrm{~h}$.

Similarly, C. geminatum JX25 grew with a wide salinity range of 15-35 PSU, but only had a significantly higher growth rate at medium salinity (18 PSU) in 48 and $72 \mathrm{~h}$ (Fig. 4e) ( $p>0.05$, multiple comparisons). High salinity (25 and 35 PSU) resulted in a decrease in cell density of JX25 with time. Inhibition abilities of JX25 in different salinity treatments significantly differed ( $p<0.05$, multiple comparisons). Inhibition percentages toward A. sanguinea at 18,25 , and $30 \mathrm{PSU}$ were $18.5,18.7$, and $30 \%$ at $72 \mathrm{~h}$, respectively, and also increased over time (Fig. 4f).

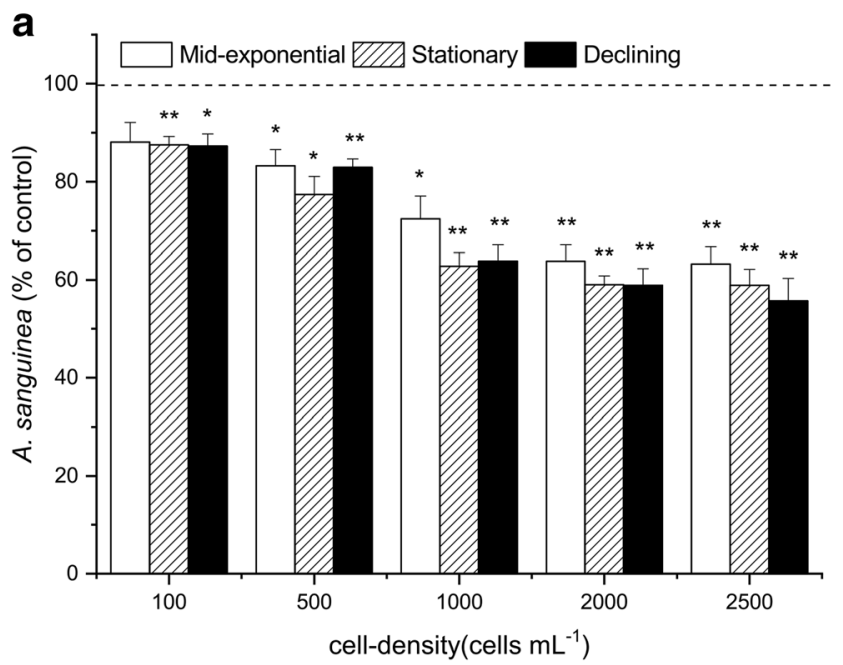

Fig. 2 Growth of A. sanguinea exposed to three different growth stages of $C$. geminatum and different initial cell densities at $72 \mathrm{~h}$. Multiple comparisons for different growth stage (a). Multiple comparisons for different initial cell densities (b). Initial cell densities A. sanguinea was 500 cells $\mathrm{mL}^{-1}$. Each data point represents the mean of triplicates $(n=3)$.

\section{Discussion}

\section{Allelopathic characteristics of C. geminatum on co-occurring phytoplankton}

Our study showed that growth of four common microalgae, $P$. micans, A. sanguinea, $K$. veneficum, and $R$. salina was significantly inhibited by $C$. geminatum, indicating that C. geminatum was allelopathic to co-occurring phytoplankton. There was no significant difference between the allelopathic effects of two strains of C. geminatum (JX25 and JX26) on A. sanguinea, indicating that allelopathy of $C$. geminatum was not confined to a single strain.

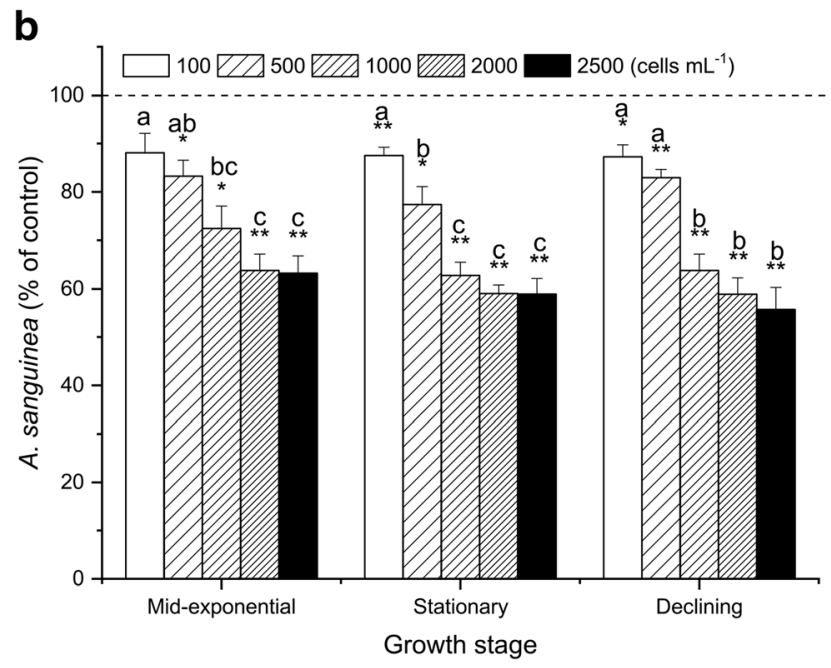

Error bars stand for +1 standard deviation of $n=3$. The allelopathic effects of significance are shown as $* p<0.05$ and $* * p<0.01$, respectively ( $t$ test). Different lowercase letters indicate significant differences ( $p<0.05$, multiple comparisons) among treatments 
Fig. 3 Growth of A. sanguinea exposed to four different components of $C$. geminatum. Initial cell densities of

C. geminatum and A. sanguinea were each 500 cells $\mathrm{mL}^{-1}$. Whole indicates whole-cell culture, Filtrate indicates filtrate of whole-cell culture, Sonicate indicates sonicated extracts, and Sonicate Filtrate indicates sonicated extracts filtrates. Each data point represents the mean of triplicates $(n=3)$. Error bars stand for +1 standard deviation of $n=$ 3 . The allelopathic effects of significance are shown as $* p<0.05$ and $* * p<0.01$, respectively ( $t$ test). Different lowercase letters indicate significant differences $(p<0.05$, multiple comparisons) among treatments

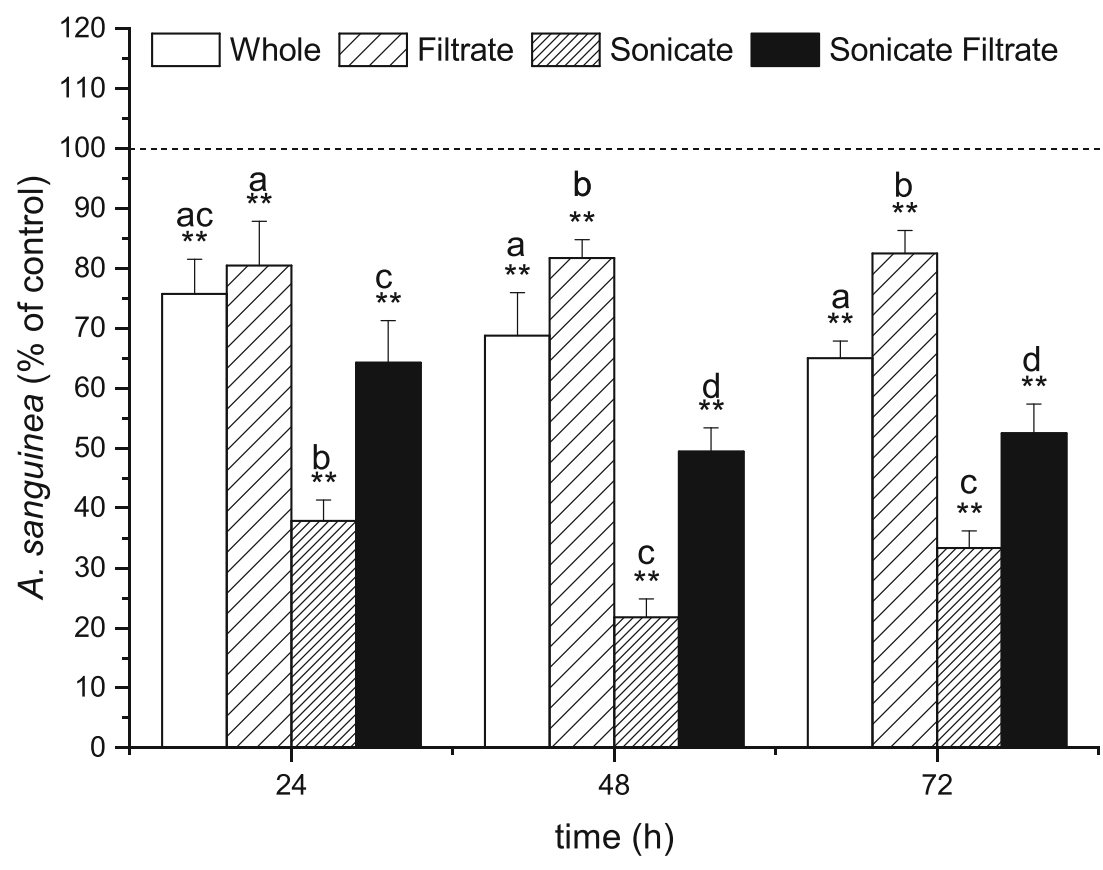

Some studies have suggested that the sensitivity of cooccurring phytoplankton is one of the most important factors affecting the allelopathic effects of harmful species (Granéli et al. 2008a; Xu et al. 2015). We found that allelopathic effects of $C$. geminatum on co-occurring phytoplankton were species-specific. For example, it was interesting that the growth of $P$. parvum was not inhibited by $C$. geminatum, and developed a higher population density (Fig. 1). Because the effect of allelopathy is an interaction between phytoplankton (Granéli and Hansen 2006; Chia et al. 2018), C. geminatum and the target species can both allelopathically affect each other in some cases. Much research has demonstrated that P. parvum can produce prymnesins and have a powerful allelopathic effect on multiple phytoplankton species (Fistarol et al. 2003). Remmel and Hambright (2012) found that $P$. parvum can use toxin-assisted micropredation in order to facilitate its growth. Thus, it seemed that $P$. parvum could even utilize organic materials from $C$. geminatum to obtain a higher growth rate. Our experiments also showed that growth of $S$. costatum was barely affected by $C$. geminatum (Fig. 1), which is in good agreement with a previous study in which $S$. costatum was not inhibited by water from HABs of C. geminatum (Wang et al. 2011). Co-evolution has been proposed to explain why some algae have resistance to allelopathy (Suikkanen et al. 2004). Many studies have shown that inhibition of $S$. costatum from multiple allelopathic species is not significant (Kubanek et al. 2005; Prince et al. 2008), and even its presence can mitigate the toxicity of other phytoplankton (Xu et al. 2017). Consequently, they can coexist with dominant microalgae during blooms, even becoming the dominant species after termination of blooms. In fact, S. costatum was observed in water samples during $C$. geminatum blooms
(Ou et al. 2010; Shen et al. 2012) and replaced it as the dominant species over predecessor allelopathic organisms following a C. geminatum bloom (Pang et al. 2015). In this sense, allelopathy plays an important role in phytoplankton community structure as well as succession during HABs and can even influence the direction of succession. Moreover, competitor sensitivity to $C$. geminatum allelopathy is variable among species, thus the allelopathic effect is species-specific.

Our results showed that cell density of $C$. geminatum was positively correlated with allelopathic intensity within the same growth stage - the higher the density of $C$. geminatum, the stronger the allelopathic effect on target species. Other researchers also have reported that the effect of allelopathy of P. parvum on target algae depends on the cell density of both algae and target algae (Granéli and Salomon 2010). These results were consistent with an earlier study that demonstrated that $P$. parvum produced more allelochemicals with increased cell density (Tillmann 2003).

The growth stage of microalgae is also an important biological factor affecting its allelopathic effects. For example, Nodularia spumigena (Cyanobacteria) in the exponential growth stage has stronger allelopathic effects on Thalassiosira weissflogii (Bacillariophyta) and Rhodomonas sp. (Cryptophyta) than in the stationary stage (Suikkanen et al. 2004). Our study showed that the three growth stages of microalgae filtrates all inhibited the growth of A. sanguinea, and the effects of inhibition from strong to weak were in order of declining, stationary, and medium exponential growth stages, especially in higher cell density groups. There was a limitation on obtaining high concentration of $C$. geminatum culture in laboratory; however, it was reasonable to assume that this variation tendency would be more remarkable at higher cell density. Pichierri et al. (2017) 
a

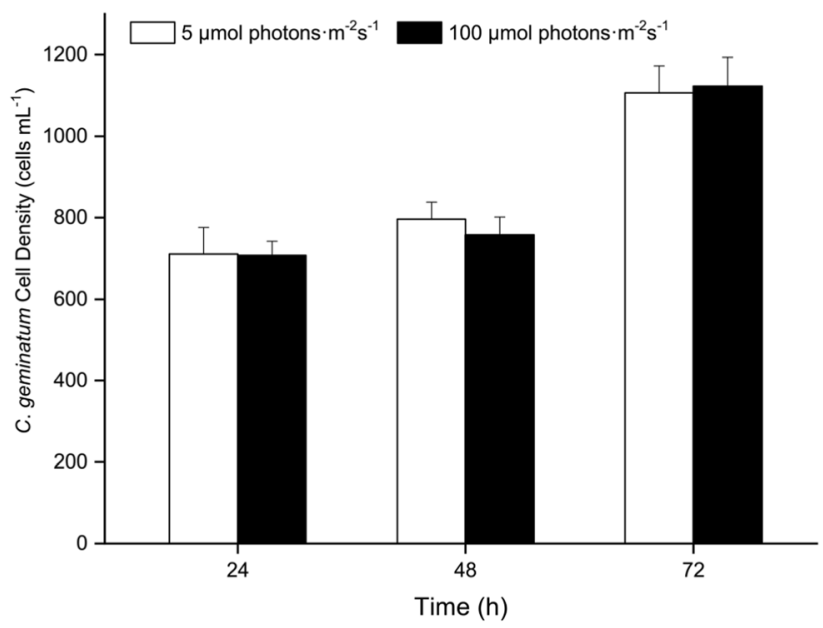

C

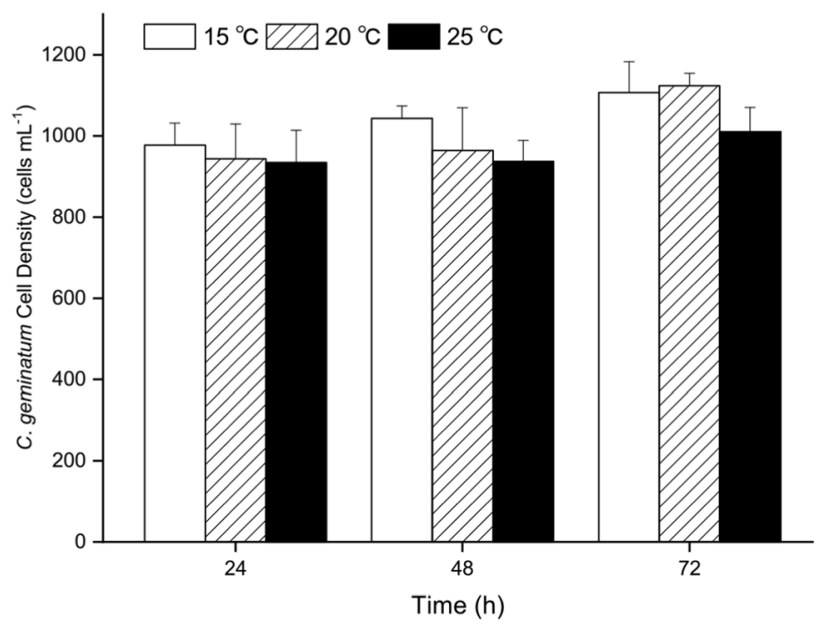

e

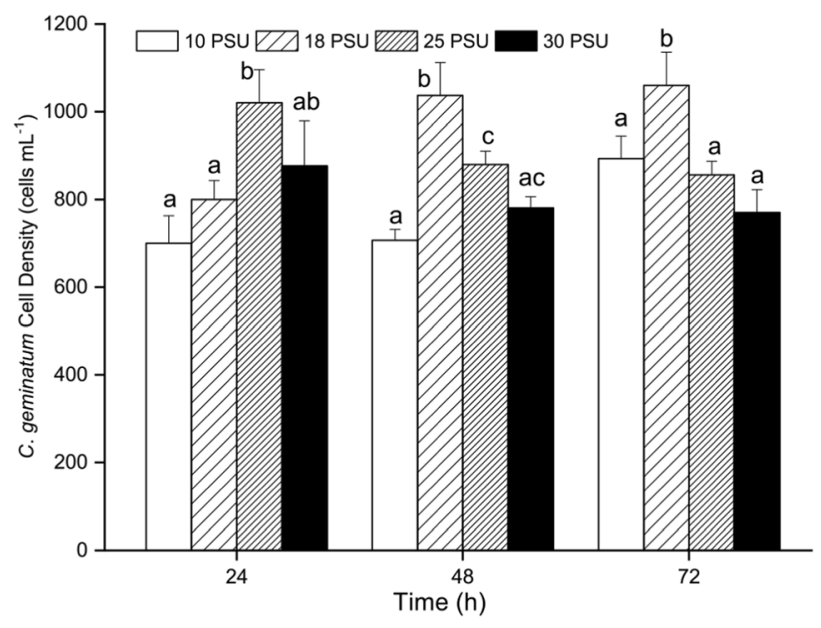

Fig. 4 Growth of $C$. geminatum (a, c, e) and effects of $C$. geminatum on growth of $A$. sanguinea $(\mathbf{b}, \mathbf{d}, \mathbf{f})$ under different environmental factors: irradiation (a, b), temperature (c, d), and salinity (e, f) within $72 \mathrm{~h}$. Initial cell densities of $C$. geminatum and $A$. sanguinea were 800 and 500 cells $\mathrm{mL}^{-1}$, respectively. Each data point represents the mean of

\section{b}

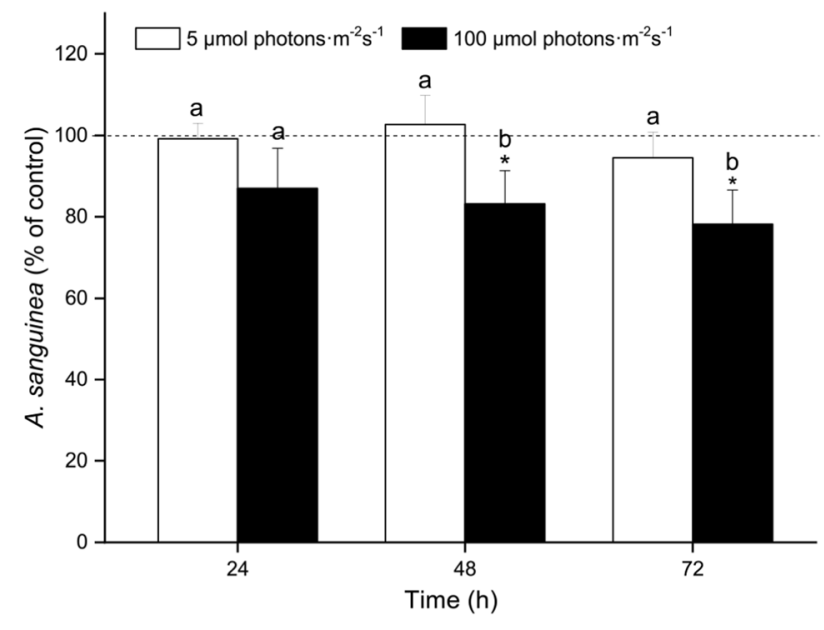

d

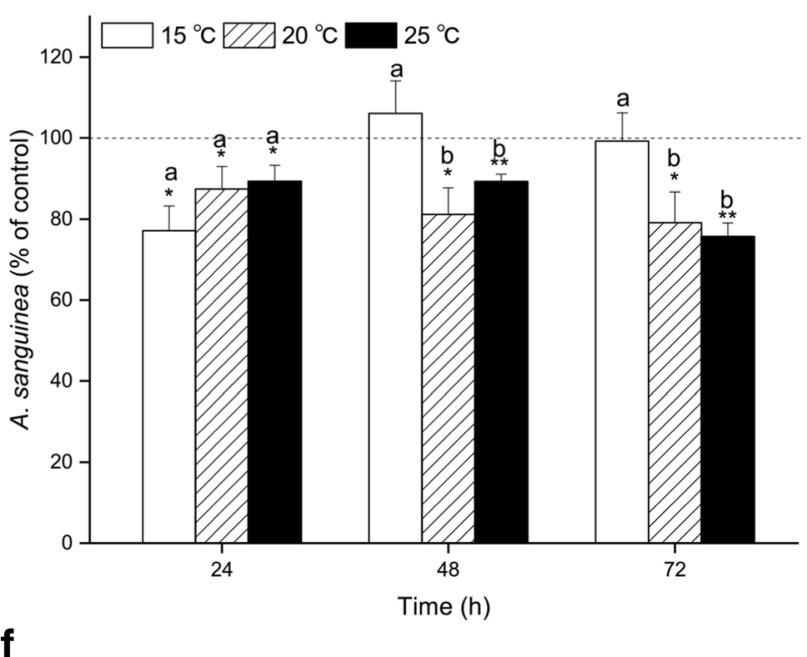

$\mathbf{f}$

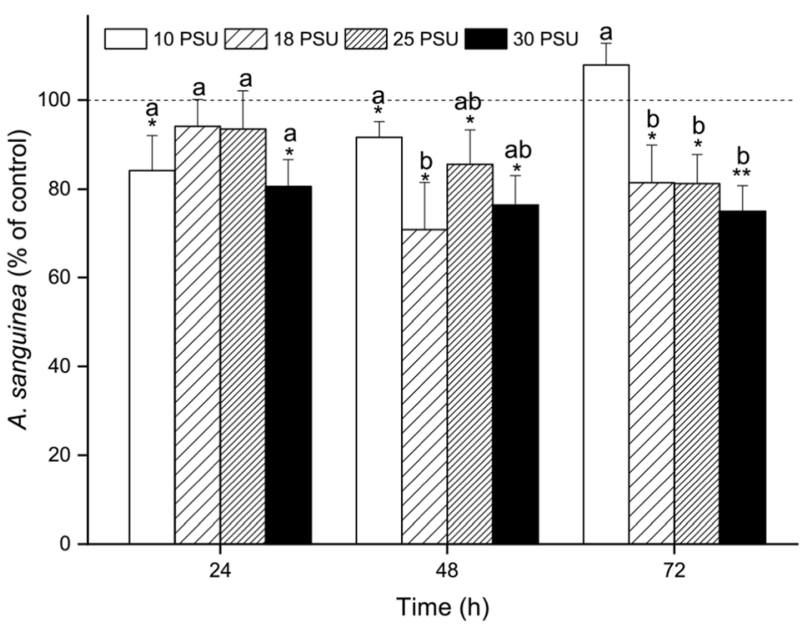

triplicates $(n=3)$. Error bars stand for +1 standard deviation of $n=3$. The allelopathic effect of significance is shown as $* p<0.05$ and $* * p<0.01$, respectively ( $t$ test). Different lowercase letters indicate significant differences ( $p<0.05$, multiple comparisons) among treatments 
found that the allelopathic effect of multiple diatom species on Ostreopsis cf. ovata (Dinoflagellata) increased with age of culture, consistent with our results. It is possible that, with prolonged culture time, the allelochemical(s) secreted into the filtrate from cells of $C$. geminatum increased and accumulated, resulting in stronger allelopathic effects in the late growth phase. Sun et al. (2012) performed a similar study, showing that the concentration of allelochemicals secreted from Isochrysis galbana (Haptophyta) to the culture medium increased from the exponential to declining growth stage, and the strongest allelopathy effect was also the declining growth stage.

In experiment 3, all the four different fractions of C. geminatum culture were able to inhibit the growth of the target species, A. sanguinea, with varying inhibition rates (Fig. 3). It is particularly meaningful to compare the relative allelopathic activity among the four different $C$. geminatum culture fractions, which provided insight into the source and characteristics of the allelochemicals and relative contributions of the intra- and extracellular allelochemicals to the effects. The filtrate of C. geminatum displayed significant and stable inhibition effects on target species, while whole culture had increasing inhibition effects during the experimental period, suggesting cells of C. geminatum can produce and release allelochemicals to ambient medium continuously and allelopathic activity is independent of live $C$. geminatum cells (or cell contact); the allelochemicals can be effective at least in $72 \mathrm{~h}$. Similarly, Qiu et al. (2012) found that the inhibition effect of $H$. akashiwo (Raphidophyceae) on A. sanguinea was stronger in co-culture than filtrate. Obviously, the stability of allelochemicals was varying among different phytoplankton species. For example, studies showed that the filtrate of P. parvum inhibited T. weissflogii (Bacillariophyta), Rhodomonas cf. baltica (Cryptophyta), and Prorocentrum minimum (Dinophyceae) in $36 \mathrm{~h}$, but the target species can recover after 36 h (Granéli and Johansson 2003; Fistarol et al. 2005). The sonicate and sonicate filtrate treatments displayed significantly higher inhibition effects on target species than those in whole culture and filtrate treatments, indicating the allelochemicals were released from $C$. geminatum and the majority of them were stored intra-cellularly, which was consistent with our previous study on the allelopathy of Pseudonitzschia spp. (Xu et al. 2015). The sonication paralleled some aspects of cell lysis and zooplankton grazing in a natural context. We believe this method was an important approach to prove that the growth-inhibiting effects observed in co-culture experiments were mainly caused by allelopathy, because it excluded effects of cell contact, nutrient competition, $\mathrm{pH}$, and light shading, and sonicated filtered treatment further excluded the effect of broken cell debris.

There were studies that showed that some dinoflagellates can prey on other target species by cell contact, such as Alexandrium pseudogonyaulax (Dinoflagellata) phagocytosed Heterocapsa rotundata (Dinoflagellata) by mucus trap (Blossom et al. 2012). Our filtrate, sonicate, and sonicate filtrate experiments provided evidence that allelopathic effects in $C$. geminatum do not rely on the existence of live cells or cell contact. While whole-cell culture and filtrate experiments established the allelopathic capability of $C$. geminatum, it is worth pointing out that the effects of digestive enzyme or other metabolites during cell lysis may be involved in inhibition effects on target species. On account of the complexity in allelopathic effects observed in the experiments, extraction and separation of allelopathic compounds from C. geminatum culture are significative, which were included in a subsequent study (Cai et al. unpublished).

\section{Effects of environmental factors on allelopathy in C. geminatum}

The allelopathic effects of $C$. geminatum were influenced by abiotic factors, such as light, temperature, and salinity. The light intensity not only affects the growth of phytoplankton, but also has some effect on its toxicity and allelopathic effects, which in turn determines interspecific competition between phytoplankton (van Rijssel et al. 2007; Prasetiya et al. 2016). Our results showed that $C$. geminatum displayed stronger allelopathic activity at higher irradiance compared to that at lower irradiance. Similarly, C. raciborskii (Cyanophyceae) had stronger allelopathic activity to Ankistrodesmus falcatus (Chlorophyceae) under high light conditions (Antunes et al. 2012). The competitor microalgae can grow well at high light intensity, which can result in fierce competition under higher irradiance. As a consequence, producing an allelochemical becomes an important strategy for increasing competitiveness of $C$. geminatum under higher irradiance.

Temperature is an important factor influencing the growth, development, reproduction, and seasonal distribution of phytoplankton, and has different effects on the metabolism of enzymes, the absorption and utilization of nutrients, and the cell division cycle (Granéli and Salomon 2010; Ma et al. 2015). However, it remains unclear how temperature changes affect phytoplankton allelopathy. Field investigation showed that a high density of $C$. geminatum occurred when temperature exceeded $26.5^{\circ} \mathrm{C}$ during blooms (Ou et al. 2010). In this study, we found the strongest inhibition abilities of $C$. geminatum for the highest temperature condition $\left(25^{\circ} \mathrm{C}\right)$; nevertheless, the temperature rise did not influence $C$. geminatum growth. The densities of A. sanguinea in the control group increased along with the rising temperature from 15 to $25^{\circ} \mathrm{C}$ during our experiment. If similar growth occurred in the treatments, it could cause an underestimation of the allelopathic activity of each $C$. germinatum cell in high temperature treatments as allelochemicals are immobilized by the greater number of target cells. Even though, we still observed higher allelopathic effects in high temperature treatments in $72 \mathrm{~h}$, supporting that allelopathic activity of C. geminatum was stronger at higher temperature. Similarly, Marion van Rijssel et al. (2007) stated that the hemolytic activity 
of Phaeocystis pouchetii (Haptophyta) was enhanced with increasing temperature and light. Our results indicated that C. geminatum needed to compete with A. sanguinea for limited resources, and the ability for allelopathy may afford C. geminatum advantages in this competition for resources, consistent with previous studies (van Rijssel et al. 2007).

Salinity has an important effect on the growth, distribution, and release of toxins from phytoplankton (Landsberg 2002). For example, Prymnesium blooms usually break out in low salinity (1-2 PSU) water bodies (Edvarsen and Paasche 1998), and ichthyotoxic C. polykrikoides expands rapidly in water of 25-40 PSU (Kim et al. 2004; Yamatogi et al. 2006; Matsuoka et al. 2008). Our results showed that growth of C. geminatum was not good with high salinity conditions (25 and 30 PSU); however, it grew normally with low salinity (10 and 18 PSU), consistent with results of a field investigation in which blooms occurred at salinity of 15.49-17.92 PSU (Ou et al. 2010). Our results showed that salinity of 18 PSU was suitable for growth of $C$. geminatum. Changes in salinity may also affect production of allelochemicals in marine microalgae (Granéli et al. 2012). In our salinity experiment, there was no inhibitory effect on A. sanguinea at the low salinity of 10 PSU by the end of the experiment; however, with increased salinity, the inhibition was significantly enhanced, indicating that high salinity may stimulate C. geminatum to produce more allelochemicals. The allelopathic effect of $C$. geminatum on co-cultured phytoplankton was significant at our tested ranges of salinity and temperature during HABs of $C$. geminatum (Pang et al. 2015). Thus, allelopathy plays a key role in the process of HABs.

\section{Ecological significance of allelopathy in C. geminatum}

A previous study indicated that HAB could not form due to allelopathy, because allelopathic effect almost only existed in very high cell density (Jonsson et al. 2009). Field study showed that the cell density of $C$. geminatum was as high as around 30, 000 cells $\mathrm{mL}^{-1}$ during the blooms (Pang et al. 2015). In experiment 2 , we observed strong allelopathic activities of $C$. geminatum on A. sanguinea in relatively lower cell density treatments. It is worth noting that even under the lowest cell density (100, 500 cells $\mathrm{mL}^{-1}$ ), the growth inhibition activities were still significant (Fig. 2). These results provided useful information supporting the potential role of allelopathic effects in the succession of phytoplankton community and the formation of $C$. geminatum blooms.

Our temperature and salinity experiments showed that C. geminatum had lower growth rates under high salinity, but its inhibition activities were stronger, compared with lower salinity conditions. It seemed that $C$. geminatum exhibited higher allelopathic effects under adverse conditions. However, metabolic energy is needed to produce allelochemical(s) for metabolism (Pan et al. 1998). More allelochemical(s) are produced by $C$. geminatum under adverse conditions with the increasing consumption of energy. Why does $C$. geminatum produce allelochemical(s) during stress? It is possible that C. geminatum inhibits other phytoplankton by increasing allelopathic activity and so increasing its competitive advantage. Thus, it compensates for adversity in order to compete for limiting resources (Granéli et al. 2008b).

Many studies have shown that target species are more sensitive to allelochemicals under stress conditions (Fistarol et al. 2005; Granéli and Hansen 2006; Granéli and Pavia 2006), meaning that it is more efficient for an allelopathic effect because of both the increasing production of allelochemical(s) and the sensitive target. Therefore, allelopathy is an important competition strategy for $C$. geminatum.

\section{Conclusions}

We found that $C$. geminatum was allelopathic to four of six competing phytoplankton species and the effect of allelopathy differed according to target species. The strongest negative impacts on A. sanguinea of four different components from C. geminatum cultures, from strong to weak, were sonicated culture, filtrates of sonicated culture, cell culture, and filtrates of whole-cell culture. However, the allelopathic intensity of C. geminatum was positively correlated with its cell density and closely associated with its growth stage, and the strongest allelopathic effect was during the declining phase. The allelopathic effect of $C$. geminatum was influenced by environmental factors including light intensity, temperature, and salinity. Moreover, the allelopathic effect increased under stress. Our results suggest that allelopathy plays an important role in phytoplankton community succession. Because $C$. geminatum is allelopathic, this may be a strategy for competition that helps it to stay dominant in maintenance of blooms.

Acknowledgments This work was supported by the National Natural Science Foundation of China (NSFC) [Grant Nos. 41576159 , 41676099]. We thank two anonymous reviewers for their careful work and thoughtful suggestions that have helped improve this paper substantially.

Open Access This article is distributed under the terms of the Creative Commons Attribution 4.0 International License (http:// creativecommons.org/licenses/by/4.0/), which permits unrestricted use, distribution, and reproduction in any medium, provided you give appropriate credit to the original author(s) and the source, provide a link to the Creative Commons license, and indicate if changes were made.

\section{References}

Allen JL, Ten-Hage L, Leflaive J (2017) Regulation of fatty acid production and release in benthic algae: could parallel allelopathy be explained with plant defence theories? Microb Ecol 75:1-13 
An SL, Jeong HJ, Jang TY, Kang NS, Jang SH, Lee MJ (2015) Differential effects of typhoons on ichthyotoxic Cochlodinium polykrikoides red tides in the South Sea of Korea during 2012 2014. Harmful Algae 45:26-32

Antunes JT, Leão PN, Vasconcelos VM (2012) Influence of biotic and abiotic factors on the allelopathic activity of the cyanobacterium Cylindrospermopsis raciborskii strain LEGE 99043. Microb Ecol 64:584-592

Blossom HE, Daugbjerg N, Hansen PJ (2012) Toxic mucus traps: a novel mechanism that mediates prey uptake in the mixotrophic dinoflagellate Alexandrium pseudogonyaulax. Harmful Algae 17:40-53

Chia MA, Jankowiak JG, Kramer BJ, Goleski JA, Huang IS, Zimba PV, do Carmo Bittencourt-Oliveira M, Gobler CJ (2018) Succession and toxicity of Microcystis and Anabaena (Dolichospermum) blooms are controlled by nutrient-dependent allelopathic interactions. Harmful Algae 74:67-77

Cleberc F, Alessandra G, Davidf B (2007) Does allelopathy contribute to Cylindrospermopsis raciborskii (Cyanobacteria) bloom occurrence and geographic expansion? J Phycol 43:256-265

Edvarsen B, Paasche E (1998) Bloom dynamics and physiology of Prymnesium and Chrysochromulina. Physiological Ecology of Harmful Algal Blooms NATO ASI Series G Ecological Sciences 41:193-208

Fistarol GO, Legrand C, Granéli E (2003) Allelopathic effect of Prymnesium parvum on a natural plankton community. Mar Ecol Prog Ser 255:115-125

Fistarol GO, Legrand C, Granéli E (2005) Allelopathic effect on a nutrient-limited phytoplankton species. Aquat Microb Ecol 41: $153-161$

Granéli E, Hansen PJ (2006) Allelopathy in harmful algae: a mechanism to compete for resources? In: Granéli E, Turner JT (eds) Ecology of harmful algae. Springer, Berlin, pp 189-201

Granéli E, Johansson N (2003) Increase in the production of allelopathic substances by Prymnesium parvum cells grown under N- or Pdeficient conditions. Harmful Algae 2:135-145

Granéli E, Pavia H (2006) Allelopathy in marine ecosystems. Allelopathy:415-431

Granéli E, Salomon PS (2010) Factors influencing allelopathy and toxicity in Prymnesium parvum. J Am Water Resour Assoc 46:108-120

Granéli E, Salomon PS, Fistarol GO (2008a) The role of allelopathy for harmful algae bloom formation. In: Evangelista V, Barsanti L, Frassanito AM, Passarelli V, Gualtieri P (eds) Algal toxins: nature, occurrence, effect and detection. Springer, Berlin, pp 159-178

Granéli E, Weberg M, Salomon PS (2008b) Harmful algal blooms of allelopathic microalgal species: the role of eutrophication. Harmful Algae 8:94-102

Granéli E, Edvardsen B, Roelke DL, Hagström JA (2012) The ecophysiology and bloom dynamics of Prymnesium spp. Harmful Algae 14: 260-270

Guo H, Liu X, Ding D, Guan C, Yi X (2014) The economic cost of red tides in China from 2008-2012. PICES Sci Rep 47:27

Iwataki M, Takayama H, Takahashi K, Matsuoka K (2015) Taxonomy and distribution of the unarmored dinoflagellates Cochlodinium polykrikoides and C. fulvescens. In: Ohtsuka S, Suzaki T, Horogushi T, Suzuki N, Not F (eds) Marine protists. Springer, Berlin, pp 551-565

Jonsson PR, Pavia H, Toth G (2009) Formation of harmful algal blooms cannot be explained by allelopathic interactions. Proc Nat Acad Sci 106:11177-11182

Keating KI (1977) Allelopathic influence on blue-green bloom sequence in a eutrophic lake. Science 196:885-887

Kim DI, Matsuyama Y, Nagasoe S, Yamaguchi M, Yoon YH, Oshima Y, Imada N, Honjo T (2004) Effects of temperature, salinity and irradiance on the growth of the harmful red tide dinoflagellate Cochlodinium polykrikoides Margalef (Dinophyceae). J Plankton Res 26:61-66
Kubanek J, Hicks MK, Naar J, Villareal TA (2005) Does the red tide dinoflagellate Karenia brevis use allelopathy to outcompete other phytoplankton? Limnol Oceanogr 50:883-895

Kudela RM, Gobler CJ (2012) Harmful dinoflagellate blooms caused by Cochlodinium sp.: global expansion and ecological strategies facilitating bloom formation. Harmful Algae 14:71-86

Lan D, Gu H (2014) Dinoflagellate cysts along the coast of China. Science Press, Beijing

Landsberg JH (2002) The effects of harmful algal blooms on aquatic organisms. Rev Fish Sci 10:113-390

Lee DK (2008) Cochlodinium polykrikoides blooms and eco-physical conditions in the South Sea of Korea. Harmful Algae 7:318-323

Lim AS, Jeong HJ, Kim JH, Lee SY (2017) Control of ichthyotoxic Cochlodinium polykrikoides using the mixotrophic dinoflagellate Alexandrium pohangense: a potential effective sustainable method. Harmful algae 63:109-118

Ma Z, Fang T, Thring RW, Li Y, Yu H, Zhou Q, Zhao M (2015) Toxic and non-toxic strains of Microcystis aeruginosa induce temperature dependent allelopathy toward growth and photosynthesis of Chlorella vulgaris. Harmful Algae 48:21-29

Matsuoka K, Iwataki M (2009) Toxonomy and geographical distribution of the harmful dinoflagellate Cochlodinium polykrikoides and related species. Bull Plankton Soc Jpn 56:27-30

Matsuoka K, Iwataki M, Kawami H (2008) Morphology and taxonomy of chain-forming species of the genus Cochlodinium (Dinophyceae). Harmful Algae 7:261-270

Matsuoka K, Mizuno A, Iwataki M, Takano Y, Yamatogi T, Yangho Y, Joonbaek L (2010) Seed populations of a harmful unarmored dinoflagellate Cochlodinium polykrikoides Margalef in the East China Sea. Harmful Algae 9:548-556

Ou L, Zhang Y, Li Y (2010) The outbreak of Cochlodinium geminatum bloom in Zhuhai, Guangdong. J Trop Oceanogr 29

Pan Y, Bates SS, Cembella AD (1998) Environmental stress and domoic acid production by Pseudo-nitzschia: a physiological perspective. Nat Toxins 6:127-135

Pang Y, Nie R, Lu SH (2015) Preliminary environmental analysis of the evolution of Cochlodinium geminatum bloom in the Pearl River Estuary. Ecol Environ Sci 24:286-293

Pedersen FM, Hansen PJ (2003) Effects of high pH on the growth and survival of six marine heterotrophic protists. Mar Ecol Prog Ser 260: 33-41

Pichierri S, Accoroni S, Pezzolesi L, Guerrini F, Romagnoli T, Pistocchi R, Totti C (2017) Allelopathic effects of diatom filtrates on the toxic benthic dinoflagellate Ostreopsis cf. ovata. Mar Environ Res:131

Prasetiya FS, Safitri I, Widowati I, Cognie B, Decottignies P, Gastineau R, Morançais M, Windarto E, Tremblay R, Mouget J-L (2016) Does allelopathy affect co-culturing Haslea ostrearia with other microalgae relevant to aquaculture? J Appl Phycol 28:2241-2254

Prince EK, Myers TL, Kubanek J (2008) Effects of harmful algal blooms on competitors: allelopathic mechanisms of the red tide dinoflagellate Karenia brevis. Limnol Oceanogr 53:531-541

Qiu X, Yamasaki Y, Shimasaki Y, Gunjikake H, Honda M, Kawaguchi M, Matsubara T, Nagasoe S, Etoh T, Matsui S (2012) Allelopathy of the raphidophyte Heterosigma akashiwo against the dinoflagellate Akashiwo sanguinea is mediated via allelochemicals and cell contact. Mar Ecol Prog Ser 446:107-118

Remmel EJ, Hambright KD (2012) Toxin-assisted micropredation: experimental evidence shows that contact micropredation rather than exotoxicity is the role of Prymnesium toxins. Ecol Lett 15:126-132

Shen P-P, Li Y-N, Qi Y-Z, Zhang L-P, Tan Y-H, Huang L-M (2012) Morphology and bloom dynamics of Cochlodinium geminatum (Schütt) Schütt in the Pearl River Estuary, South China Sea. Harmful Algae 13:10-19

Śliwińska-Wilczewska S, Pniewski F, Latała A (2016) Allelopathic activity of the picocyanobacterium Synechococcus $s p$. under varied light, temperature, and salinity conditions. Int Rev Hydrobiol 101:69-77 
Smayda TJ (1997) Harmful algal blooms: their ecophysiology and general relevance to phytoplankton blooms in the sea. Limnol Oceanogr 42:1137-1153

Steidinger KA, Haddad K (1981) Biologic and hydrographic aspects of red tides. Bioscience 31:814-819

Suikkanen S, Fistarol GO, Granéli E (2004) Allelopathic effects of the Baltic cyanobacteria Nodularia spumdigena, Aphanizomenon flosaquae and Anabaena lemmermannii on algal monocultures. J Exp Mar Biol Ecol 308:85-101

Sun Y, Xu S, Li W, Zhang J, Wang C (2012) Antialgal substances from Isochrysis galbana and its effects on the growth of Isochrysis galbana and six species of feed microalgae. In: Zhu E, Sambath S (eds) Information technology and agricultural engineering. Springer, Berlin, pp 211-223

Tang YZ, Gobler CJ (2009) Characterization of the toxicity of Cochlodinium polykrikoides isolates from northeast US estuaries to finfish and shellfish. Harmful Algae 8:454-462

Tillmann U, Alpermann T, John U, Cembella A (2008) Allelochemical interactions and short-term effects of the dinoflagellate Alexandrium on selected photoautotrophic and heterotrophic protists. Harmful Algae 7:52-64

van Rijssel M, Alderkamp A-C, Nejstgaard JC, Sazhin AF, Verity PG (2007) Haemolytic activity of live Phaeocystis pouchetii during mesocosm blooms. Biogeochemistry 83:189-200
Wang Z, Jiang S, Gu Y (2011) Effects of Cochlodinium bloom in Pearl River Estuary in China on the growth of other harmful algal bloom species. J Shenzhen Univ Sci Eng 28:553-558

Xu N, Tang YZ, Qin J, Duan S, Gobler CJ (2015) Ability of the marine diatoms Pseudo-nitzschia multiseries and P. pungens to inhibit the growth of co-occurring phytoplankton via allelopathy. Aquat Microb Ecol 74:29-41

Xu N, Wang M, Tang Y, Zhang Q, Duan S, Gobler CJ (2017) Acute toxicity of the cosmopolitan bloom-forming dinoflagellate Akashiwo sanguinea to finfish, shellfish, and zooplankton. Aquat Microb Ecol 80:209-222

Yamatogi T, Sakaguchi M, Iwataki M, Matsuoka K (2006) Effects of temperature and salinity on the growth of four harmful red tide flagellates occurring in Isahaya Bay in Ariake Sound, Japan. Nippon Suisan Gakkaishi 72:160-168

Zhang T, Tang S, Zhan H (2017) Using satellite sensors and in situ observations to monitor phytoplankton blooms in the Pearl River Estuary. J Coast Res 34:451-459

Publisher's note Springer Nature remains neutral with regard to jurisdictional claims in published maps and institutional affiliations. 